\title{
Calcium Carbonate Crystal Forms Formed from Sea Water by Inorganic Processes*
}

\author{
Yasushi KITANO** and Donald W. HoOD***
}

\begin{abstract}
This study was made to solve the following questions: (1) Which of the three crystal forms of calcium carbonate (calcite, aragonite and vaterite) is produced most predominantly from sea water by inorganic processes. (2) Which of the chemical constituents of sea water has the greatest influence on the polymorphic formation of calcium carbonate? The experimental results show that aragonite alone is favored in sea water media because of the strong influence of magnesium in the water on the crystal formation of calcium carbonate.
\end{abstract}

\section{Introduction}

This study was undertaken to determine the polymorphic form of calcium carbonate formed by inorganic precipitation in sea water. The following considerations are important and necessary for understanding the inorganic precipitation, and the results will be available for the study on diagnosis of marine calcareous sediments: (1) Which of the three crystal forms of calcium carbonate (calcite, aragonite and vaterite) is produced most predominantly from sea water by inorganic processes. (2) Which of the chemical constituents of sea water has the greatest influence on the polymorphic crystallization of calcium carbonate.

It has been reported that aragonite formation is favored when calcium carbonate is precipitated from sea water without the immediate participation of organic agencies (MONAGHAN et al., 1954; SMITH, 1940; VAUGHAN, 1924).

However, no satisfactory explanation has yet been advanced for this. The purpose of this work was to solve this problem. In the experiments, calcium carbonate was prepared from a calcium bicarbonate solution by escape of carbon dioxide gas from the solution. This reaction was used because: (1) It is one of

* Received July 2, 1962

** Present address, Water Research Laboratory, Faculty of Science, Nagoya University, Nagoya, Japan

*** Department of Oceanography, A \& M College of Texas, College Station, Texas, U.S.A. "homogeneous precipitation" reactions; therefore reproducible precipitates can be obtained easily. (2) The effect of elements on the crystal formation can be studied because the mother solution does not contain any ion other than calcium and carbonate ions.

Various ions were added to calcium bicarbonate solutions, and the solutions were left to stand for two or three weeks. The calcium carbonate formed was collected and the crystal form identified.

In connection with the program of this report, the following finding can be obtained from the data to be published in separate paper (KITANO, 1962 a): Ions in sea water having an influence on the polymorphic formation of calcium carbonate are $\mathrm{Na}^{+}$, $\mathrm{Mg}^{2+}, \mathrm{Ca}^{2+}, \mathrm{Sr}^{2+}, \mathrm{Cl}^{-}, \mathrm{HCO}_{3}{ }^{-}$, and $\mathrm{SO}_{4}{ }^{2-}$. Compounds which have a great influence on the crystal formation were chosen from salts to be expected in sea water; $\mathrm{NaCl}, \mathrm{NaHCO}_{3}, \mathrm{Na}_{2} \mathrm{SO}_{4}$, $\mathrm{MgCl}_{2}, \mathrm{CaCl}_{2}$ and Sr-bicarbonate.

\section{Experimental}

Materials and solutions

Calcium bicarbonate solution: A calcium carbonate suspension in distilled water was bubbled with carbon dioxide gas for one day and then filtered. The filtrate was bubbled again with carbon dioxide for one hour.

Strontium bicarbonate solution: A strontium carbonate suspension was similarly treated as for the calcium bicarb onate solution.

Concentrated sea water: Sea water was 
evaporated over a water bath to one-fourth of its original volume.

Materials: Analytical reagent grade $\mathrm{NaCl}$, $\mathrm{NaHCO}_{3}, \mathrm{Na}_{2} \mathrm{SO}_{4}, \mathrm{MgCl}_{2} \bullet 6 \mathrm{H}_{2} \mathrm{O}$, and $\mathrm{CaCl}_{2}$ were used.

Procedure

All combinations of the following salts: $\mathrm{NaCl}, \mathrm{MgCl}_{2}, \mathrm{CaCl}_{2}, \mathrm{Na}_{2} \mathrm{SO}_{4}, \mathrm{NaHCO}_{3}$ and strontium bicarbonate were dissolved in one liter flasks with $30 \mathrm{ml}$ of distilled water. Three hundred $\mathrm{ml}$ of the calcium bicarbonate solution were then added to each of the flasks. The amounts of the salts in solutions were such that their concentrations were equal to those in sea water.

Fifty or $100 \mathrm{ml}$ of the concentrated sea water were transferred to other flasks, and 150 or $300 \mathrm{ml}$ of the calcium bicarbonate solution were then added.

The flasks were left to stand at room temperature for 2 to 3 weeks so that carbon dioxide escaped from the solutions and calcium carbonate crystals separated. The crystals formed were filtered off and washed several times with distilled water until they were free of the mother solution. After being dried in an air bath and ground in an agate mortar, the crystal form of calcium carbonate was identified by the X-ray diffractometer technique.

\section{Discussion of Results}

The results obtained are shown in Tables $1-3$, and from them the following can be seen: (1) According to Tables 1 and 2, the magnesium in the mother solution had the greatest influence on the polymorphic formation of cal- cium carbonate among all other chemical constituents in the media. Aragonite formation alone was favored because of the magnesium in the mother solution, in which the concentration of magnesium was equal to that in sea water $\left(\mathrm{Mg}^{2+}: 1.2 \mathrm{~g} /\right.$ liter $)$. Work is under way to investigate the mechanism for the strong effect of magnesium (KITANO, 1962 a). The inorganic precipitation of the aragonite form of $\mathrm{CaCO}_{3}$ is most probable in sea water (Table 3), since sea water contains magnesium $(1.2 \mathrm{~g} /$ liter $)$. In dilute sea water, a significant percentage of calcite was found with aragonite (Table 3); this is due to decrease in magnesium content in solution and to more favorable conditions for calcite precipitation (Fig. 1). (3) Vaterite was not formed under the conditions of the experiments. This is explained by the result presented in another publication (KITANO, $1962 \mathrm{~b}$ ); vaterite formation increased with increase in the temperature and the concentration of $\mathrm{NaCl}$ in the mother solution, but $\mathrm{MgCl}_{2}$ greatly inhibited vaterite formation. Vaterite was never formed in water at a temperature of less than $40^{\circ} \mathrm{C}$ when the water contained $23 \mathrm{~g}$ of $\mathrm{NaCl}$ and $5 \mathrm{~g}$ of $\mathrm{MgCl}_{2}$ in one liter, because of the high concentration of magnesium.

It must also be noted that calcium carbonate precipitates were formed from solutions having $\mathrm{pH}$ values between 7 and $8.8^{*}$ and various $\mathrm{Ca}: \mathrm{Mg}$ ratios**. Therefore, it can be expected aragonite alone is formed by inorganic processes throughout the entire body*** of sea water.

* $\mathrm{CaCO}_{3}$ separated from bicarbonate solution as $\mathrm{CO}_{2}$ escaped from the solution; therefore the pH of solution changed during the process of the $\mathrm{CaCO}_{3}$ separation.

** Calcium was precipitated as $\mathrm{CaCO}_{3}$ but magnesium was not coprecipitated with the carbonate (Tables 1 and 2) (KITANo, 1962 a). *,** It took 2 to 3 weeks to prepare $\mathrm{CaCO}_{3}$ crystals in the experiments. The author studied whether there was difference in the polymorphic composition among the $\mathrm{CaCO}_{3}$ crystals produced during different periods. Under the conditions of the present experiments, the difference was not significant.

*** The experiment was not done at temperature of lower than $10 \pm 2^{\circ} \mathrm{C}$ (Fig. 1). Even at temperature of lower than $10^{\circ} \mathrm{C}$ aragonite alone will be produced in sea water media because of the high magnesium concentration.

According to JAMIESON's report (JAMIESON, 1953), calcite is a stable modification at a low pressure; therefore, aragonite formation is expected in sea water under a high hydrostatic pressure. In the actual ocean, $\mathrm{CaCO}_{3}$ is not formed under the high hydrostatic pressure (HINDMAN, 1943; PARK, 1961). 
Table 1. $\mathrm{Ca}\left(\mathrm{HCO}_{3}\right)_{2}-\mathrm{MgCl}_{2}-\mathrm{NaCl}-\mathrm{Na}_{2} \mathrm{SO}_{4}-\mathrm{CaCl} 2-\mathrm{Sr}\left(\mathrm{HCO}_{3}\right)_{2}-\mathrm{CO}_{2}-\mathrm{H}_{2} \mathrm{O}$ System.

$\left(15 \pm 2^{\circ} \mathrm{C}\right)$

\begin{tabular}{|c|c|c|c|c|c|c|c|c|c|c|}
\hline \multirow{2}{*}{$\begin{array}{c}\text { Ca-bicarbonate* } \\
\text { solution } \\
\text { Ca } \\
\mathrm{mg} \\
\end{array}$} & \multicolumn{4}{|c|}{$\begin{array}{l}\text { nitial composition of solutions } \\
\text { (total volume } 330 \mathrm{ml} ; \mathrm{pH} 6.5 \text { ) }\end{array}$} & & \multirow{2}{*}{$\begin{array}{l}\text { On } \\
\text { the } \\
20 \text { th } \\
\text { day } \\
\mathrm{pH}\end{array}$} & \multicolumn{3}{|c|}{$\begin{array}{l}\text { Crystal form of } \mathrm{CaCO}_{3} \\
\text { formed during a } 20 \text { day } \\
\text { period }\end{array}$} & \multirow{2}{*}{$\begin{array}{c}\mathrm{Mg} \text { content in } \\
\mathrm{CaCO}_{3} \text { formed } \\
\text { during a } 20 \\
\text { day period } \\
\mathrm{Mg} \\
\%\end{array}$} \\
\hline & $\begin{array}{l}\mathrm{MgCl}_{2} \\
\mathrm{~g}\end{array}$ & $\mathrm{NaCl}$ & $\begin{array}{c}\mathrm{Na}_{2} \mathrm{SO}_{4} \\
\mathrm{~g}\end{array}$ & $\begin{array}{c}\mathrm{CaCl}_{2} \\
\mathrm{~g}\end{array}$ & $\begin{array}{l}\text { or-bicarbonate** } \\
\text { solution } \\
\mathrm{Sr} \\
\mathrm{mg}\end{array}$ & & $\begin{array}{c}\text { vatelite } \\
\%\end{array}$ & $\begin{array}{c}\text { aragonite } \\
\%\end{array}$ & calcite & \\
\hline 90 & 0 & 0 & 0 & 0 & 0 & 7.7 & 0 & 0 & 100 & - \\
\hline " & 1.64 & 0 & 0 & 0 & 0 & 8.5 & 0 & 100 & 0 & 0.0 \\
\hline " & 0 & 7.82 & 0 & 0 & 0 & 8.5 & 0 & 0 & 100 & - \\
\hline " & 0 & 0 & 1.31 & 0 & 0 & 8.5 & 0 & 0 & 100 & - \\
\hline " & 0 & $0^{\circ}$ & 0 & 0.37 & 0 & 8.2 & 0 & 0 & 100 & - \\
\hline " & 0 & 0 & 0 & 0 & 3 & 7.7 & 0 & 0 & 100 & - \\
\hline " & 1.64 & 7.82 & 0 & 0 & 0 & 8.5 & 0 & 100 & 0 & 0.0 \\
\hline " & 1.64 & 0 & 1.31 & 0 & 0 & 8.5 & 0 & 100 & 0 & 0.0 \\
\hline " & 1.64 & 0 & 0 & 0.37 & 0 & 8.4 & 0 & 99 & 1 & 0.0 \\
\hline " & 1.64 & 0 & 0 & 0 & 3 & 8.5 & 0 & 100 & 0 & 0.0 \\
\hline " & 0 & 7.82 & 1.31 & 0 & 0 & 8.5 & 0 & 0 & 100 & - \\
\hline " & 0 & 7.82 & 0 & 0.37 & 0 & 8.5 & 0 & 0 & 100 & - \\
\hline " & 0 & 7.82 & 0 & 0 & 3 & 8.5 & 0 & 0 & 100 & - \\
\hline " & 0 & 0 & 1.31 & 0.37 & 0 & 8.1 & 0 & 0 & 100 & - \\
\hline " & 0 & 0 & 1.31 & 0 & 3 & 8.1 & 0 & 0 & 100 & - \\
\hline " & 0 & 0 & 0 & 0.37 & 3 & 8.0 & 0 & 0 & 100 & - \\
\hline " & 1.64 & 7.82 & 1.31 & 0 & 0 & 8.4 & 0 & 100 & 0 & 0.0 \\
\hline " & 1.64 & 7.82 & 0 & 0.37 & 0 & 8.5 & 0 & 100 & 0 & 0.0 \\
\hline " & 1.64 & 7.82 & 0 & 0 & 3 & 8.5 & 0 & 100 & 0 & 0.0 \\
\hline " & 1.64 & 0 & 1.31 & 0.37 & 0 & 8.5 & 0 & 100 & 0 & 0.0 \\
\hline " & 1.64 & 0 & 0 & 0.37 & 3 & 8.4 & 0 & 99 & 1 & 0.0 \\
\hline " & 1.64 & 0 & 1.31 & 0 & 3 & 8.5 & 0 & 100 & 0 & 0.0 \\
\hline " & 0 & 7.82 & 1.31 & 0.37 & 0 & 8.5 & 0 & 0 & 100 & - \\
\hline " & 0 & 7.82 & 1.31 & 0 & 3 & 8.5 & 0 & 0 & 100 & - \\
\hline " & 0 & 7.82 & 0 & 0.37 & 3 & 8.5 & 0 & 0 & 100 & - \\
\hline " & 0 & 0 & 1.31 & 0.37 & 3 & 8.5 & 0 & 0 & 100 & - \\
\hline " & 1.64 & 7.82 & 1.31 & 0.37 & 0 & 8.5 & 0 & 100 & 0 & 0.0 \\
\hline " & 1.64 & 7.82 & 1.31 & 0 & 3 & 8.5 & 0 & 100 & 0 & 0.0 \\
\hline " & 1.64 & 7.82 & 0 & 0.37 & 3 & 8.5 & 0 & 100 & 0 & 0.0 \\
\hline " & 1.64 & $\dot{0}$ & 1.31 & 0.37 & 3 & 8.4 & 0 & 100 & 0 & 0.0 \\
\hline " & 0 & 7.82 & 1.31 & 0.37 & 3 & 8.5 & 0 & 0 & 100 & - \\
\hline " & 1.64 & 7.82 & 1.31 & 0.37 & 3 & 8.5 & 0 & 100 & 0 & 0.0 \\
\hline
\end{tabular}

* Solution containing $\mathrm{Ca}\left(\mathrm{HCO}_{3}\right)_{2}, \mathrm{H}_{2} \mathrm{CO}_{3}, \mathrm{CO}_{2}$ and $\mathrm{H}_{2} \mathrm{O}$, as shown in "Experimental".

** Solution containing $\mathrm{Sr}\left(\mathrm{HCO}_{3}\right)_{2}, \mathrm{H}_{2} \mathrm{CO}_{3}, \mathrm{CO}_{2}$ and $\mathrm{H}_{2} \mathrm{O}$, as shown in "Experimental". 
Table 2. $\mathrm{Ca}\left(\mathrm{HCO}_{3}\right)_{2}-\mathrm{MgCl}_{2}-\mathrm{NaCl}-\mathrm{Na}_{2} \mathrm{SO}_{4}-\mathrm{CaCl}_{2}-\mathrm{NaHCO}_{3}-\mathrm{CO}_{2}-\mathrm{H}_{2} \mathrm{O}$ System.

$$
\left(29 \pm 2^{\circ} \mathrm{C}\right)
$$

\begin{tabular}{|c|c|c|c|c|c|c|c|c|c|c|}
\hline \multirow{3}{*}{$\begin{array}{c}\text { Ca-bicarbonate } \\
\text { solution } \\
\mathrm{Ca} \\
\mathrm{mg}\end{array}$} & \multicolumn{4}{|c|}{$\begin{array}{l}\text { Initial composition of solutions } \\
\text { (total volume } 330 \mathrm{ml} ; \mathrm{pH} 6.5 \text { ) }\end{array}$} & & \multirow{3}{*}{$\begin{array}{l}\text { On } \\
\text { the } \\
14 \text { th } \\
\text { day } \\
\text { pH }\end{array}$} & \multicolumn{3}{|c|}{$\begin{array}{l}\text { Crystal form of } \mathrm{CaCO}_{3} \\
\text { formed during a } 14 \text { day } \\
\text { period }\end{array}$} & \multirow{3}{*}{$\begin{array}{c}\mathrm{Mg} \text { content in } \\
\mathrm{CaCO}_{3} \text { formed } \\
\text { during a } 14 \\
\text { day period } \\
\mathrm{Mg} \\
\%\end{array}$} \\
\hline & \multirow{2}{*}{$\begin{array}{l}\mathrm{MgCl}_{2} \\
\mathrm{~g}\end{array}$} & \multirow{2}{*}{$\begin{array}{l}\mathrm{NaCl} \\
\mathrm{g}\end{array}$} & \multirow{2}{*}{$\begin{array}{c}\mathrm{Na}_{2} \mathrm{SO}_{4} \\
\mathrm{~g}\end{array}$} & \multirow{2}{*}{$\begin{array}{c}\mathrm{CaCl}_{2} \\
\mathrm{~g}\end{array}$} & \multirow{2}{*}{$\begin{array}{c}\mathrm{NaHCO}_{3} \\
\mathrm{~g}\end{array}$} & & \multicolumn{2}{|c|}{ Vaterite Aragonite } & \multirow{2}{*}{$\begin{array}{c}\text { Calcite } \\
\%\end{array}$} & \\
\hline & & & & & & & $\%$ & $\%$ & & \\
\hline 90 & 0 & 0 & 0 & 0 & 0 & 8.2 & 0 & 10 & 90 & - \\
\hline " & 1.64 & 0 & 0 & 0 & 0.064 & 8.6 & 0 & 100 & 0 & 0.0 \\
\hline " & 1.64 & 7.82 & 0 & 0 & 0.064 & 8.6 & 0 & 100 & 0 & 0.0 \\
\hline " & 1.64 & 0 & 1.31 & 0 & 0.064 & 8.6 & 0 & 100 & 0 & 0.0 \\
\hline " & 1.64 & 0 & 0 & 0.37 & 0.064 & 8.0 & 0 & 100 & 0 & 0.0 \\
\hline " & 1.64 & 7.82 & 1.31 & 0 & 0.064 & 8.6 & 0 & 100 & 0 & 0.0 \\
\hline " & 1.64 & 7.82 & 0 & 0.37 & 0.064 & 8.1 & 0 & 100 & 0 & 0.0 \\
\hline " & 1.64 & 0 & 1.31 & 0.37 & 0.064 & 8.1 & 0 & 100 & 0 & 0.0 \\
\hline " & 1.64 & 7.82 & 1.31 & 0.37 & 0.064 & 8.2 & 0 & 100 & 0 & 0.0 \\
\hline " & 0 & 7.82 & 0 & 0 & 0.064 & 8.5 & 0 & 10 & 90 & - \\
\hline " & 0 & 0 & 1.31 & 0 & 0.064 & 8.5 & 0 & 20 & 80 & - \\
\hline " & 0 & 0 & 0 & 0.37 & 0.064 & 7.9 & 0 & 10 & 90 & - \\
\hline " & 0 & 7.82 & 1.31 & 0 & 0.064 & 8.5 & 0 & 10 & 90 & - \\
\hline " & 0 & 7.82 & 0 & 0.37 & 0.064 & 8.1 & 0 & 10 & 90 & - \\
\hline " & 0 & 0 & 1.31 & 0.37 & 0.064 & 8.0 & 0 & 20 & 80 & - \\
\hline " & 0 & 7.82 & 1.31 & 0.37 & 0.064 & 8.0 & 0 & 20 & 80 & - \\
\hline
\end{tabular}

Table 3. $\mathrm{Ca}\left(\mathrm{CO}_{3}\right)_{2}-\mathrm{CO}_{2}-\mathrm{H}_{2} \mathrm{O}-$ Concentrated Sea Water System.

$\left(15 \pm 2^{\circ} \mathrm{C}\right)$

\begin{tabular}{|c|c|c|c|c|c|c|}
\hline \multirow{2}{*}{\multicolumn{2}{|c|}{$\begin{array}{c}\text { Ca-bicarbonate } \\
\text { solution }\end{array}$}} & \multirow{3}{*}{$\begin{array}{c}\text { Concentrated } \\
\text { sea water } \\
\text { ml }\end{array}$} & \multirow{2}{*}{\multicolumn{3}{|c|}{$\begin{array}{l}\text { Crystal from of } \mathrm{CaCO}_{3} \\
\text { formed during a } 20 \text { day } \\
\text { period }\end{array}$}} & \multirow{3}{*}{$\begin{array}{c}\text { Concentration of salt } \\
\text { in solution } \\
\begin{array}{c}\text { Concentration of salt } \\
\text { in sea water }\end{array}\end{array}$} \\
\hline & & & & & & \\
\hline $\mathrm{ml}$ & $\begin{array}{l}\mathrm{Ca} \\
\mathrm{mg}\end{array}$ & & $\begin{array}{c}\text { Vaterite } \\
\%\end{array}$ & $\overbrace{\%}^{\text {Aragonite }}$ & $\begin{array}{c}\text { Calcite } \\
\%\end{array}$ & \\
\hline 150 & 40 & 100 & 0 & 99 & 1 & 1.6 \\
\hline 300 & 80 & 100 & 0 & 99 & 1 & 1 \\
\hline 300 & 80 & 50 & 0 & 93 & 7 & 0.55 \\
\hline 300 & 80 & 0 & 0 & 0 & 100 & 0 \\
\hline
\end{tabular}




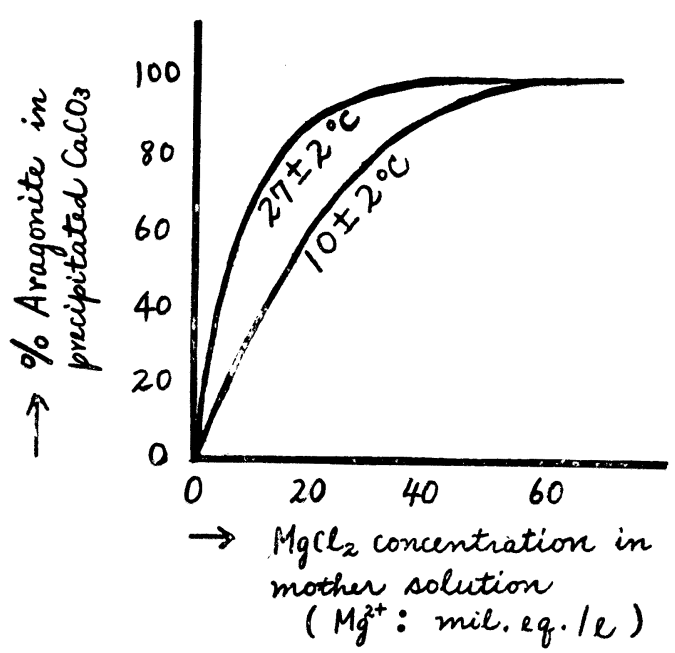

Fig. 1. Effect of $\mathrm{MgCl}_{\mathbf{2}}$ in mother solution on crystal from of $\mathrm{CaCO}_{3}$.

\section{Conclusion}

When calcium carbonate is precipitated from sea water bo inorganic processes, aragonite formation alone is favored because of the strong influence of the magnesium in the water on the polymorphic crystalization of calcium carbonate.

\section{Acknowledgements}

The authors express their thanks to Miss Lila M. JEFFERY and Dr. Brian W. LOGAN in A \& $M$ College of Texas for their critical reading of the manuscript.

\section{References}

H.Indman, J. C. (1943): Properties of the system $\mathrm{CaCO}_{3}-\mathrm{CO}_{2}-\mathrm{H}_{2} \mathrm{O}$ in sea water and sodium chloride solutions. Ph. D. Thesis, Univ. Calif. Los Angeles.

JAMIEson, J. C. (1953): Phase equilibrium in the system calcite-aragonite. Jour. Chem. Phys., 21, 1385-1390.

KitanO, Y. (1962a); Behavior of various inorganic ions in the process of calcium carbonate separation from bicarbonate separation from bicarbonate solution, (in press), Bull. Chem. Soc. Japan, 35, No. 12.

KitANO, Y. (1962b); A study of polymorphic formation of calcium carbonate in thermal springs with emphasis on the effect of temperature. (in press), Bull. Chem. Soc. Japan, 35, No. 12.

Monaghan, P. H. and M. L. Lytle (1956): The origin of calcareous oöliths. Jour. Sedim. Petrol., 26, 111-118.

PARK, K. (1961): A study of calcium carbonate chemistry in the oceans with emphasis on the effect of dissolved organic matter. Ph. D. Thesis A \& M College of Texas. College Station, Texas.

Smith, C. L. (1940): The Great Bahama Bank. II. Calcium carbonate precipitation. Jour. Mar. Res., 3, 171-189.

VAUGHAN, T. W. (1924): Oceanography in its relation to other earth sciences. Washington Acad. Sci., 14, 307-333. 